\title{
DOELPROGRAMMERING EN DE FINANCIELE STRUKTUUR VAN DE ONDERNEMING
}

door Drs. H. J. J. Bronsema en Drs. F. M. Tempelaar

\section{Inleiding}

In dit artikel beogen we een verband te leggen tussen de „moderne" theorie inzake het ondernemingsgedrag en een oplossingstechniek uit het operationele onderzoek. In het kader van het onderhavige themanummer van dit tijdschrift, waarin de rol van de wiskunde in de bedrijfsekonomie centraal staat, passen wij de doelprogrammeringstechniek (welke zich met name van de lineaire algebra bedient) toe op de problematiek van de besluitvorming met betrekking tot de ondernemingsfinanciering (in ruime zin; ook de investeringsproblematiek van de onderneming vatten wij er onder).

Allereerst worden (in par. 2) de uitgangspunten samengevat van twee theoretische benaderingen van het ondernemingsgedrag, t.w. de "neo-klassieke" ondernemingstheorie (,theory of the firm") en de intern-gedragstheorie van de onderneming (,,behavioral theory of the firm"). Deze bespreking sluit aan op enkele recente publikaties in Nederlandse tijdschriften $\left.[6 ; 7 ; 14 ; 21]^{1}\right)$. In het kort gaan we in op de implikaties van deze benaderingen voor de besluitvorming betreffende de financiering.

Nadat (in par. 3) de techniek van de doelprogrammering is besproken, geven we (in par. 4) een voorbeeld van toepassing van deze techniek op het gebied van de financiering. Het betreft een doelprogrammeringsmodel voor de (tijdruimtelijke) ontwikkeling van een bevredigende financiële struktuur van de onderneming. Voor de theoretische opbouw van het model wordt met name gebruik gemaakt van pogingen die de laatste jaren in de Nederlandse literatuur zijn gedaan om de intern-gedragsbenadering ,in te brengen" in de bedrijfsekonomische theorie $[2 ; 3 ; 4]$, en in de financieringstheorie in het bijzonder $[2 ; 5 ; 23 ; 24]$.

De gehanteerde oplossingsmethode van doelprogrammering (,,goalprogramming") vormt een uitbreiding van de lineaire programmeringstechniek. De methode werd ongeveer 15 jaar geleden ontwikkeld $[9 ; 10 ; 15]$, en is sindsdien enkele malen in de (vooral Angelsaksische) literatuur toegepast op bedrijfsekonomische vraagstukken (bijv. $[11 ; 15 ; 22]$ ). Daarnaast zijn ook andere toepassingen bekend, zoals recentelijk ten behoeve van stadsplanning [12], en planning en beheer van universiteiten [18].

\section{Theorieën van het ondernemingsgedrag; implikaties voor de financiële planning}

\subsection{Besluitvorming en financiële planning}

De hieronder te bespreken ondernemingstheorieën betreffen beide een specifikatie van het ondernemingsgedrag, waarin de besluitvorming centraal staat. Voor een duidelijk inzicht in de uitgangspunten van de beide benade-

1) De tussen haken $1 /$ geplaatste getallen in dit arrikel verwijzen naar de litcratuurlijst, pp. 258 e.v. 
ringen is het dienstig het besluitvormingsproces als volgt te "ontrafelen":

- er zijn alternatieven, waaruit een keuze moet worden gedaan;

- afhankelijk van „de omstandigheden” (data) leidt elk alternatief tot bepaalde resultaten;

- op basis van een voorkeursordening (preferentiefunktie) t.a.v. de resultaten wordt (met behulp van een selektiekriterium) gekozen uit de alternatieven. In dit licht zien wij de problematiek van de financiële struktuur van de onderneming als een besluitvormingsvraagstuk. Dit vraagstuk van de financiële struktuur omvat niet alleen het probleem van de omvang en samenstelling van het vermogen van de onderneming (financieringsprobleem ,in enge zin"), maar ook dat van de samenstelling van het kapitaalgoederenkomplex waarin het vermogen wordt vastgelegd (investeringsprobleem) - alsmede de onderlinge (wederzijdse) samenhang tussen kapitaal en vermogen. Spreken wij in het navolgende van financiële planning, dan doelen wij op het beslissingsproces, dat is gericht op de totstandkoming (tijdruimtelijk gezien: de ontwikkeling) van de financiële struktuur van de onderneming. De struktuur komt tot stand c.q. wijzigt als gevolg van een verzameling ,akties" (gedrag), die worden geinduceerd door beslissingen aangaande de relevante beheersbare faktoren ${ }^{2}$ ). Aldus resulteert de financiële struktuur als gevolg van een (deel-)beslissingsproces in de onderneming: uit de alternatieve mogelijkheden dient, gelet op de resultaten die elk der alternatieven teweeg kan brengen, gekozen te worden in het licht van de (sub-)doelstelling(en) van de onderneming.

\subsection{De holistische benadering, optimalisatie en de financieringstheorie}

$\mathrm{De}$ in de inleiding genoemde "neo-klassieke" ondernemingstheorie kenmerkt zich vooral door haar holistische uitgangspunt: de onderneming wordt opgevat als een entiteit, als één beslissingscentrum (,de ondernemer"), waar alle gegevens samenkomen en alle besluiten worden genomen; het gedrag van de onderneming staat gelijk met het gedrag van de ondernemer. Terzake van de holistische besluitvorming worden in deze theorie (welke men o.a. aantreft in de mikro-ekonomische prijstheorie) enkele zeer belangrijke veronderstellingen gemaakt. In de eerste plaats wordt de beslisser alwetendheid toegeschreven met betrekking tot de alternatieven: hij kent alle relevante alternatieven. Voorts wordt verondersteld dat hij in staat is de resultaten van alle alternatieven te bepalen en tegen elkaar af te wegen. Terzake van dit laatste wordt ervan uitgegaan, dat de beslisser in staat is een eenduidige en volledige voorkeursordening aan te brengen met behulp van een gegeven preferentiefunktie; hij wordt geacht te streven naar de maximalisatie (c.q. minimalisatie) van één doelvariabele.

Aldus is een dergelijke beslisser-ondernemer steeds in staat tot de keuze van het optimale alternatief. (Gegeven de bovenvermelde veronderstellingen heeft het resultaat van dit optimale alternatief het karakter van een ,,maximum maximorum".) Aangezien zijn preferentiefunktie in de tijd konstant wordt geacht, zal zijn keuzegedrag steeds konsistent zijn. De oplossingstech-

2) Vergelijk $[13$, p. 7): , . . in feite toch is de structuur slechts gestolde actie, ..."

$m a b$ blz. 242 
nieken, die worden toegepast in modellen die berusten op de bovenbeschreven uitgangspunten, hebben het karakter van optimalisatie-methoden. Zo wordt in dit verband veel gebruik gemaakt van differentiaalrekening, die (uiteraard slechts indien en voor zover de gespecificeerde relaties aan de „,rekenvoorwaarden" voldoen) steeds de maximale, c.q. minimale uitkomst levert.

Een verfijning in het bovenbeschreven besluitvormingsproces kan worden aangebracht, door de keuzevrijheid van de beslisser beperkt te achten door één of meer randvoorwaarden. Er ontstaat dan een probleem van optimalisatie onder beperkende nevenvoorwaarden. (Opgemerkt zij, dat de aard van deze nevenvoorwaarden zodanig kan zijn, dat het een besluitvormingssituatie betreft zoals beschreven in par. 2.3.) Vooral de techniek van het lineaire programmeren - veelvuldig toegepast in bedrijfsekonomische modellen - biedt in dergelijke gevallen de methode voor het doen van de optimale keuze (uiteraard mits voldaan is aan de vereisten omtrent lineariteit).

Samengevat luiden de voornaamste genoemde uitgangspunten:

- alle relevante alternatieven zijn bekend;

- alle relevante datakonstellaties zijn bekend, en alle resultaten zijn bepaalbaar en bekend;

- de preferentiefunktie van de beslisser is gegeven en in de tijd konstant; hij streeft naar de keuze van het optimale alternatief.

De aldus beschreven alwetend rationele beslisser uit de "neo-klassieke" (ondernemings)theorie, door ons ook wel te noemen: holistische optimalisatietheorie, is typerend voor een groot aantal modellen uit de bedrijfsekono$\mathrm{mie}^{3}$ ). Onderzoek in de literatuur naar besluitvormingsmodellen betreffende de ondernemingsfinanciering wijst uit dat deze veelal als uitgangspunt hebben, dat de beslisser (ondernemer) streeft naar maximalisatie van de waarde van de onderneming voor de eigenaren. (Zie bijv. MAO [20, p. 18] alsmede WILLEMS [25, pp. 116 e.v.] voor een kritische bespreking hiervan.) In de uitgebreide literatuur over de ondernemingsfinanciering worden vraagstukken aan de orde gesteld zoals o.m.:

- de vaststelling van de totale investeringsomvang;

- selektie van afzonderlijke of samengevoegde investeringsprojekten;

- bepaling van de omvang en samenstelling van het werkkapitaal;

- keuze van het vermogen, ter dekking van de financieringsbehoefte;

- bepaling van de gewenste vermogensstruktuur;

- vaststelling van de dividendpolitiek;

waarvoor afzonderlijk of in onderlinge samenhang theorieën en modellen worden ontwikkeld, die dikwijls impliciet of expliciet berusten op de in het bovenstaande samengevatte uitgangspunten. In de meeste gevallen wordt getracht tot optimale oplossingen te komen. Voor een uitvoerige samenvatting van dergelijke modellen zij verwezen naar MAO [20]; een kort overzicht van de historische ontwikkeling van de financieringstheorie is recentelijk gegeven door DE JONG [17].

Het ligt ver buiten de opzet van dit artikel in te gaan op deze en andere

3) Vergl. ook bijv. [7]. 
optimalisatietheorieën. De holistische optimalisatie dient ons in feite slechts als „kontrastscherm"4) voor de in de volgende paragraaf te bespreken gedragstheoretische benadering.

\subsection{De intern-gedragstheorie, en de implikaties voor de financiële planning}

\subsubsection{De uitgangspunten van de intern-gedragstheorie}

De door CYERT en MARCH [8] geformuleerde ,behavioral theory of the firm" (door ons te noemen: intern-gedragstheorie) is een synthese van een aantal theoretische ,elementen", waaronder als belangrijkste genoemd kunnen worden:

- de besluitvormingstheorie bij begrensde rationaliteit (de zgn. satisfactietheorie);

- de niet-holistische organisatietheorie: de organisatie gezien als een geheel van met elkaar samenwerkende (groepen van) participanten.

In de theorie van de besluitvorming bij begrensde rationaliteit [23] wordt, in tegenstelling tot de in par. 2.2 besproken alwetend rationele ondernemer, de beslisser als niet alwetend beschouwd:

- hij kent niet alle alternatieven;

- niet alle relevante data zijn hem bekend; zodat

- de mogelijke resultaten der alternatieven niet alle op voorhand bekend of bepaalbaar zijn.

De gegevens, waarover de beslisser beschikt, zijn dus beperkt. Daarnaast wordt er uitdrukkelijk vanuit gegaan dat

- de preferentiefunktie van de beslisser geen volledige ordening vertoont, en niet konstant in de tijd behoeft te zijn.

Het relatieve belang van de alternatieven zal voor de beslisser dan ook niet altijd eenduidig vastliggen. De preferentiefunktie, aan de hand waarvan deze waardering tot stand moet komen, staat hem veelal niet duidelijk operationeel voor ogen (en kan in de tijd veranderen). Deze niet-eenduidigheid geld $t$ temeer, daar het resultaat van een alternatief meerdere dimensies kan hebben, die niet zondermeer op eenzelfde ,noemer" te herleiden zijn.

In een dergelijke situatie wordt de besluitvorming gekenschetst als begrensd rationeel: hij zoekt niet naar ,het" maximum, maar tracht bevredigende oplossingen te vinden (,satisfying behaviour"). Beslissingen worden niet genomen op grond van een veronderstelde volledige voorkeursordening van alle alternatieven, maar op grond van een partiële ordening van de bekende alternatieven: ordening in bevredigende en niet-bevredigende alternatieven. Het kriterium voor deze rangschikking is het aspiratieniveau (d.i. de minimaal c.q. maximaal akseptabele waarde) dat de beslisser met betrekking tot de doelvariabele hanteert. Een dergelijk aspiratieniveau is in de regel niet konstant in de loop van de tijd; voor een bespreking van het proces dat wijzigingen in de geaspireerde waarden teweeg kan brengen, zij verwezen naar de literatuur $[19 ; 4]$.

\footnotetext{
4) Een dergelijke ,kontrastering" treft men duidelijk aan in enkele recente publikaties: $16 ; 7 ; 14$. 211 .
}

$\begin{array}{lll}m a & b & b l z .\end{array} 244$ 
Indien voor een beslisser meerdere relevante doelvariabelen zijn te onderscheiden, die niet zonder meer in een ",bovenliggende" doelfunktie zijn te „vertalen", is het mogelijk voor elke doelvariabele een aspiratieniveau te stellen. Een alternatief kan dan slechts bevredigend worden genoemd, indien het resultaat ervan tegelijkertijd voldoet aan ieder van deze aspiratieniveaus. Kan niet simultaan aan alle gestelde aspiratieniveaus worden voldaan dan is er in eerste instantie geen bevredigende oplossing voorhanden. Voor een beschrijving van het zoekproces, dat zich dan kan ontwikkelen, zij opnieuw verwezen naar de literatuur $[19 ; 4]$.

De bovenbeschreven benadering krijgt nog meer relief door haar niet alleen op het besluitvormingsproces van een individu, maar op dat van een (ondernemings-)organisatie als geheel toe te passen. In de intern-gedragstheorie wordt de onderneming (als organisatie) gezien als een geheel van (groepen van) participanten, die elk ,bijdragen” aan de organisatie leveren en in ruil daarvoor ,vergoedingen" ontvangen. De vergoedingen dienen zodanig te zijn, dat ze naar het oordeel van de participanten niet lager gewaardeerd worden dan de geleverde bijdragen. De organisatie als geheel is "levensvatbaar" zolang de aan de organisatie geleverde bijdragen toereikend zijn om daaruit (na transformatie) al de vergoedingen te verstrek ken, die nodig zijn om de bijdragen te kunnen blijven verwerven.

Evenals de individuele beslisser, waarvan in het voorgaande sprake was, kunnen de participanten binnen de organisatie worden beschouwd als begrensd rationeel. Er heerst een gedeeltelijke onwetendheid aangaande alternatieven, data en resultaten; de preferentiefunkties zijn niet steeds eenduidig, en leiden veelal slechts tot partiële ordening. In een dergelijke situatie zullen de doeleinden van de participanten luiden in de vorm van aspiratieniveaus. Indien er in een organisatie aan al de gestelde aspiratieniveaus gelijktijdig kan worden voldaan, is er sprake van een levensvatbare organisatie: door blijvende medewerking der participanten is de kontinuiteit verzekerd.

Het is denkbaar, en zelfs waarschijnlijk, dat de belangen (voorkeursordeningen) van de participanten niet volledig parallel lopen; hun doelstellingen kunnen op verschillende punten konflikteren: de gestelde aspiratieniveaus kunnen onderling inkonsistent zijn. Als gevolg hiervan is het mogelijk, dat niet aan alle aspiratieniveaus tegelijk kan worden voldaan. Ook hier gaan we niet in op een beschrijving van het zoekproces, dat dan word geinduceerd. Leidt een dergelijk proces uiteindelijk niet tot het bereiken van bevredigende oplossingen, dan zullen de aspiraties der participanten ter diskussie komen te staan, wil de organisatie ,intakt" blijven. In dit proces van ,onderhandelingen" speelt het relatieve gewicht (uit hoofde van machtsposities, onmisbaarheid, e.d.) dat aan het bereiken van bepaalde aspiraties wordt toegerekend, een belangrijke rol. Aldus is er op elk moment een zekere hiërarchie in de aspiraties voorstelbaar: aspiratieniveaus hebben bepaalde prioriteiten, ,,gewichten" (dit vormt een belangrijk uitgangspunt in de funktionering van het model in par. 4.2).

De in een zekere situatie ,overeengekomen" en door de participanten geaspireerde vergoedingen in ruil voor hun geleverde bijdragen, dragen voor 
een deel het karakter van beleidsafspraken. Deze beleidsafspraken bepalen de doelstellingen voor de onderneming als geheel, die dan ook in deze opvatting de vorm van aspiratieniveaus hebben. Ze vormen de "grote lijnen" van het beleid, dat tot uitgangspunt dient voor de planning op langere termijn ${ }^{5}$ ). Door wederzijdse afstemming komen de aspiraties tenslotte tot uitdrukking in de plannen en begrotingen op de korte termijn.

\subsubsection{Implikaties van de intern-gedragstheorie voor de financiële planning} Beperken we ons tot de recente Nederlandse financieringsliteratuur, dan valt te konstateren, dat hierin herhaaldelijk verwijzingen plaats vinden naar de bovenbeschreven intern-gedragstheorie, en dat meerdere pogingen zijn gedaan elementen van deze benadering te integreren in de bestaande financieringstheorieën. Zo tracht WILLEMS [25] een operationele methode te ontwikkelen ter bepaling van de in de investeringsselektie te hanteren ,kritische rentabiliteit", waarbij hij met name uitgaat van de satisfactiebenadering. In zijn argumentatie keert hij zich sterk tegen de veronderstelling van de maximalisatie van de (beurs)waarde van de onderneming als kriterium voor de investerings- en financieringsbeslissingen. Naar zijn mening is dit kriterium niet aktueel en niet hanteerbaar voor het investerings- en financieringsbeleid, waarvoor hij o.m. de volgende argumenten aanvoert:

- twijfel t.a.v. de veronderstelde identifikatie van de leiding met de eigenaren-aandeelhouders;

- de betrokkenen hebben verschillende preferenties;

- verschillende doelvariabelen zijn niet zonder meer op een kwantitatieve noemer te brengen (b.v. zeggenschap, rentabiliteit, weerstandsvermogen); - er is sprake van een begrensd-rationele besluitvorming.

Naar zijn mening zal het investerings- en financieringsbeleid gericht zijn op het vinden van bevredigende oplossingen, waarbij dient te worden uitgegaan van de belangen der participanten.

BOUMA presenteert, uitgaande van de intern-gedragsbenadering, een model ter bepaling van het uitkeerbare vermogenssurplus $[2 ; 5]$, en ontwikkelt een dynamisch model voor een bevredigende financiële struktuur [5]. Bij zijn theoretische argumentatie ziet hij, evenals WILLEMS, de beleidsvorming en planning op lange termijn als substituut voor het veelal ontbreken van eenduidige, operationele doelstellingen en voor de onvolledige informatie terzake van de relatie tussen bijv. financiële struktuur en doelstellingen. Uit deze beleidsvorming resulteren de ,aanwijzingen", veelal met het karakter van aspiratieniveaus, voor de besluitvorming m.b.t. de diverse aspekten van het ondernemingsgebeuren, w.o. investeren en financieren.

Evenals WILLEMS en BOUMA verwijst ook TRAAS [24] bij zijn theorievorming betreffende het investerings-financieringsprobleem uitdrukkelijk naar de intern-gedragstheorie. Zonder volledigheid na te streven, kunnen van zijn overwegingen o.a. de volgende worden genoemd:

- terzake van de financiële struktuur gelden meerdere, mogelijk konflikteren-

5) Men denke in dit verband aan de door ANSOFF [1] gegeven indeling in strategische-, organisatorische- en operationele planning. De genoemde beleidsafspraken dragen een strategisch karakter; het in par. 4 beschreven model speelt vooral in de organisatorische planningfase.

$m a b$ blz. 246 
de doelstellingen: levensvatbaarheid, interne kracht, groei;

- ten gevolge van onvoldoende gegevens met betrekking tot alternatieven bestaat er behoefte aan een overzicht van de grote lijnen van het beleid (strategische planning);

- teneinde een financieel beleid zonder ernstige schokken te kunnen realiseren, zijn „target ratio's" betreffende dividendpolitiek en financiële struktuur vereist, die geldigheid bezitten voor de lange termijn.

In het in par. 4 beschreven model hebben wij ons voor de praktische inhoud van aspiraties met name gebaseerd op de bovengenoemde literatuur.

\section{Doelprogrammering}

De doelprogrammeringsmethode is een speciale uitbreiding van de techniek van het lineaire programmeren. Met lineaire programmering kunnen problemen worden opgelost die gekarakteriseerd zijn door de volgende vorm: maximaliseer (minimaliseer): een doelstellingsfunktie, onder voorwaarde dat: aan een aantal beperkingen (gelijkheden of ongelijkheden) wordt voldaan, waarbij zowel de doelstellingsfunktie als de beperkingen lineaire relaties van de betreffende variabelen zijn. De beperkingen hebben een dwingend karakter: indien er niet simultaan aan voldaan wordt, is er geen oplossing mogelijk. Uitdrukkelijk zij opgemerkt dat het model één doelvariabele kent; de bij lineaire programmering toegepaste oplossingstechniek (de zgn. simplexmethode) is er op gericht deze variabele te maximaliseren (minimaliseren), en zodoende een optimale waarde voor de beslissingsvariabelen te vinden.

Ter illustratie volgt een eenvoudige lineaire programmeringsformulering:

maximaliseer:

$$
\mathrm{f}=\mathrm{x}_{1}+2 \mathrm{x}_{2}
$$

onder de voorwaarden: $\quad x_{1}+x_{2} \leq 4$

$$
\begin{aligned}
x_{2} & \leq 3 \\
2 x_{1} & +\frac{1}{2} x_{2} \geq 1
\end{aligned}
$$$$
x_{1}, x_{2} \geq 0
$$

(Ter toelichting zij de oplossing gegeven: $\mathrm{f}_{\mathrm{max}}=7$ voor $\mathrm{x}_{1}=1$ en $\mathrm{x}_{2}=3$ ).

Een meer algemene formulering voor een lineair programmeringsprobleem is:

maximaliseer:

$$
f=\sum_{j=1}^{n} c_{j} \cdot x_{j}
$$

onder de voorwaarden: $\quad \sum_{j}^{n}{ }_{1}^{n} a_{i j} \cdot x_{j} \gtreqless b_{i} \quad$ voor $i=1,2, \ldots, m$

$$
x_{j} \geq 0 \quad \text { voor } j=1,2, \ldots, n \text {. }
$$

De essentie van doelprogrammering schuilt in het feit dat in het model „doelen" kunnen worden opgenomen, waarnaar in de oplossing kan worden 
gestreefd. Dit geschiedt door (naast de andere nevenvoorwaarden), ,target constraints" op te nemen, waarin dit doel wordt gesteld. Ter toelichting gaan we uit van het bovenbeschreven voorbeeld van een lineair programmeringsmodel. Stel dat men terzake van de doelvariabele $f$ een ,target" wenst na te streven van 3. In dat geval luidt de doelprogrammeringsformulering van het probleem:

minimaliseer:

$$
\mathrm{g}=\mathrm{y}^{+}+\mathrm{y}^{-}
$$

onder de voorwaarden: $x_{1}+x_{2} \leq 4$

$$
\begin{aligned}
& \quad x_{2} \leq 3 \\
& 2 x_{1}+\frac{1}{2} x_{2} \geq 1 \\
& x_{1}+2 x_{2}-y^{+}+y^{-}=3 \\
& x_{1}, x_{2}, y^{+}, y^{-} \geq 0
\end{aligned}
$$

De vergelijking $(b)$ in dit stelsel geeft aan dat voor $\left(x_{1}+2 x_{2}\right)$ de waarde 3 moet worden nagestreefd, echter laat daarbij uitdrukkelijk de mogelijkheid open dat dit doel wordt overschreden ( $\mathrm{y}^{+}$krijgt een positieve waarde) of niet bereikt $\left(\mathrm{y}^{-}\right.$krijgt een positieve waarde). De doelstellingsfunktie (a) geeft evenwel aan dat dit overschrijden of ,onderbereiken" moet worden tegengegaan: $\mathrm{y}^{+}$en $\mathrm{y}^{-}$moeten zo klein mogelijk worden gemaakt; geldt voor beide $=$ 0 dan is het doel exakt bereikt.

Het is uiteraard mogelijk in een model meerdere van dergelijke „target constraints" op te nemen, elk voorzien van het ,koppel" afwijkingsvariabelen $y_{i}^{+}$en $y_{i}^{-}$, Door van alle afwijkingsvariabelen bepaalde wel en andere niet in de doelstellingsfunktie (minimand) op te nemen, wordt het mogelijk nuanceringen aan te brengen bij het nastreven van de doelen: neemt men bijv. een $y_{i}^{+}$wel op en de bijbehorende $y_{i}^{-}$niet (d.w.z. met een koëfficient gelijk aan nul) dan geeft men daarmee aan het gestelde doel als ,bovengrens" te zien (onderbereiking wordt niet bezwaarlijk geacht). Zou in het gegeven voorbeeld de minimand (a) luiden: $\mathrm{g}=0 \cdot \mathrm{y}^{+}+1 \cdot \mathrm{y}^{-}$, dan fungeert vergelijking (b) in feite als ongelijkheid $x_{1}+2 x_{2} \geq 3$ (die evenwel niet absoluut dwingend is, aangezien $\mathrm{y}^{-}$een positieve waarde kàn blijven behouden!).

Algemeen geformuleerd zou een doelprogrammeringsprobleem kunnen luiden:

minimaliseer:

$$
g=\sum_{i=m+1}^{m+p}\left(W_{i 1} \cdot y_{i}^{+}+W_{i 2} \cdot y_{i}^{-}\right)
$$

onder de voorwaarden: $\sum_{j=1}^{n} a_{i j} \cdot x_{j} \gtreqless b_{i} \quad$ voor $i=1,2, \ldots, m$

$$
\begin{array}{ll}
\sum_{j=1}^{n} a_{i j} \cdot x_{j}-y_{i}^{*}+y_{i}^{--}=b_{i} & \text { voor } i=m+1, \ldots, m+p \\
x_{j}, y_{i}^{+}, y_{i}^{-} \geq 0 & \text { voor } j=1,2, \ldots, n \\
& \text { en } i=m+1, \ldots, m+p
\end{array}
$$


waarin $p$,target-constraints" zijn opgenomen. De koëfficiënten $W_{i}$ in de minimand fungeren als ,wegingsfaktoren" voor de opgenomen afwijkingsvariabelen. Door wegingskoëfficiënten van verschillende grootte op te nemen, bereikt men dat aan het minimaliseren van de bijbehorende afwijkingsvariabelen een verschillend, ,gewicht" wordt toegekend. Aldus wordt het mogelijk in het model prioriteiten aan te brengen betreffende het bereiken (resp. overschrijden of onderbereiken) van de verschillende gestelde doelen $\left.(, \text { targets") })^{6}\right)$.

Bezien we de doelprogrammeringsbenadering in het licht van de in par. 2.3 beschreven intern-gedragstheorie, dan blijken er een aantal duidelijke aanknopingspunten te zijn:

- de methode maakt het mogelijk meerdere (eventueel strijdige) doelvariabelen tegelijkertijd te beschouwen (meerdere participanten met eigen doelen);

- de doelstellingen kunnen worden behandeld als minimaal of maximaal-aanvaardbare waarden (participanten stellen aspiratieniveaus);

- terzake van de verschillende doelen kunnen prioriteitsklassen en/of wegingskoëfficiënten worden toegekend (in de organisatie bestaan prioriteiten voor bepaalde aspiraties).

Bij het in par. 4 ontwikkelde model zijn we uitgegaan van deze eigenschappen. Er worden een aantal aspiraties betreffende de financiële struktuur gedefiniëerd in de vorm van ",target constraints". De aard van de aspiraties bepaalt welke afwijkingsvariabelen in de minimand worden opgenomen. Door de opgenomen afwijkingsvariabelen te voorzien van koëfficiënten ${ }^{7}$ ) wordt een afspiegeling bereikt van de prioriteiten die verondersteld kunnen worden terzake van de aspiraties. De geformuleerde aspiraties zijn op een aantal punten onderling strijdig, zodat in de uiteindelijke oplossing niet aan alle aspiraties tegelijk kan worden voldaan; dit blijkt dan uit de waarde van de minimand (niet volledig geminimaliseerd); een aantal der opgenomen afwijkingsvariabelen blijft $>0$.

4 Doelprogrammering en de tijdruimtelijke ontwikkeling van een bevredigende financiële struktuur; een toepassing

\subsection{Beschrijuing van het model}

Bij de opzet van het onderstaande model zijn we uitgegaan van het door BOUMA gekonstrueerde model betreffende ,winstinhouding, aandelenemissie en expansie" [5, pp. 404. e.v.], alsmede zijn ,,winstuitkeringsmodel" [5, pp. 400-404], hetgeen ook tot uitdrukking komt in de door ons gekozen symbolen. Het model is opgebouwd uit relaties tussen een aantal variabelen uit het financiële beslissingsgebied van de onderneming. Deze relaties zijn in

6) Voor een uitgebreide bespreking van de doelprogrammeringsmethode, zie o.a. [15].

$7)$ Deze koëfficiënten kunnen zodanig verschillend van elkaar worden gekozen (bijv. $10^{12}, 10^{\circ}, 1$ ) dat het programma bij de oplossing eerst de afwijkingsvariabele(n) met de hoogste koëfficiënt volledig minimaliseert (d.i. de betreffende aspiratie geheel bevredigt), eventueel ten koste van andere afwijkingsvariabelen uit een ,lagere klasse" (d.i. behorend bij aspiraties van geringere prioriteit). 
een meer-perioden vorm gespecificeerd. Elke periode moeten, uitgaande van de gegeven startwaarden voor ,periode 0", door het model waarden worden toegekend aan de variabelen, hetgeen de weergave is van de keuze tussen alternatieve investeringen, vermogensbedragen etc.; het tijdruimtelijke verloop van deze waarden geeft a.h.w. weer het ondernemingsgedrag met betrekking tot de financiële struktuur. Aan dit gedrag wordt een aantal eisen en beperkingen gesteld, zoals die zijn geformuleerd in het kader van de beleidsvorming binnen de onderneming. In het model worden deze eisen en restrikties weergegeven door middel van aspiratievergelijkingen, de „target-constraints" uit de doelprogrammeringsformulering.

Het model kent een planninghorizon van 7 beslissingsperioden (jaren). De gekozen formulering is sterk gesimplificeerd, aangezien het primaire doel van dit model een illustratie is. Voor elke periode gelden de volgende balans en resultatenrekening:

BALANS per ultimo periode $t$ :

\begin{tabular}{ll|ll}
\hline Reële aktiva & $\mathrm{R}_{\mathrm{t}}$ & Eigen vermogen & $\mathrm{A}_{\mathrm{t}}$ \\
Liquide middelen & $\mathrm{L}_{\mathrm{t}}$ & Vreemd vermogen & $\mathrm{B}_{t}$ \\
\cline { 2 - 3 } & $\mathrm{T}_{\mathrm{t}}$ & Totaal vermogen & $\frac{\mathrm{T}_{\mathrm{t}}}{\text { Geinvesteerd vermogen }}$
\end{tabular}

RESULTATENREKENING over periode $t$ :

Netto ontvangsten

af: Afschrijvingen

Interest vreemd vermogen $k_{B} \cdot B_{t-1}$

Winst voor aftrek belastingen $Z_{t}-A S_{t}-k_{B} \cdot B_{t-1}$

af: Belastingen

Netto winst

$W_{t}=\frac{f\left(Z_{t}-A F S_{t}-k_{B} \cdot B_{t-1}\right)}{(1-f)\left(Z_{t}-A F S_{t}-k_{B} \cdot B_{t-1}\right)}$

WINSTVERDELING:

In te houden winst

$\mathrm{RS}_{\mathrm{t}}$

Uit te keren winst

$\frac{\mathrm{DU}_{\mathrm{t}}}{\mathrm{W}_{\mathrm{t}}}$

Het model kent twee typen relaties, t.w. „,boekhoudkundige relaties” door middel waarvan per periode de begin- en eindbalans alsmede de resultatenrekening worden gegeven, resp. kunnen worden voortgebracht; en ,aspiratievergelijkingen", waarin de gestelde eisen en restrikties worden beschreven. In de bijlage 1 is de volledige beschrijving voor een periode opgenomen; onderstaand zullen de relaties afzonderlijk worden toegelicht. $\left.{ }^{8}\right)^{9}$ )

8) De balansvariabelen hebben een ,voorraadkarakter": ze zijn gedefinieerd op een tijdstip (nl. aan het einde van de periode); de overige variabelen hebben een "stroomkarakter": ze zijn gedefinieerd over een tijdvak, per periode (eenvoudigheidshalve is bij berekeningen aangenomen dat de stromen zich aan het einde van de periode voltrekken).

9) Het onderstaande model vertoont overeenkomsten met het in [16] gepresenteerde model; een belangrijk verschilpunt is dat dit laatste model vooral gericht is op de ,voortbrenging" van "stroom"grootheden voor één periode, terwijl het door ons gepresenteerde model primair de ontwikkeling van „voorraad"grootheden over een reeks van perioden beoogt. Daarnaast is er verschil in de oplossingsmethode (lineaire programmering versus doelprogrammering).

$m a b$ blz. 250 
Toelichting ,boekhoudkundige relaties”, voor periode $t(t=1,2, \ldots, 7)$. (1) $R_{t}=R_{t-1}-A F S_{t}+I N V_{t}$; de reële aktiva aan het einde van de periode zijn gelijk aan die van het begin van de periode, vermeerderd resp. verminderd met de investeringen resp. de afschrijvingen gedurende die periode.

(2) $\mathrm{L}_{\mathrm{t}}=\mathrm{L}_{\mathrm{t}-1}+\mathrm{W}_{\mathrm{t}}+\mathrm{AFS}_{\mathrm{t}}-\mathrm{DU}_{\mathrm{t}}+\mathrm{MS}_{\mathrm{t}}+\left(\mathrm{B}_{\mathrm{t}}-\mathrm{B}_{\mathrm{t}-1}\right)-\mathrm{INV}_{\mathrm{t}}$; geeft een overzicht van de kasstromen ( $\mathrm{MS}_{\mathrm{t}}=$ aandelenemissie in periode $\mathrm{t}$ ).

(3) $T_{t}=R_{t}+L_{t}$; definieert het totale geinvesteerde vermogen.

(4) $A_{t}=A_{t-1}+R S_{t}+M S_{t}$; toont de mutaties in het eigen vermogen (bij de werking van het model is een voorziening getroffen, waardoor $\mathrm{RS}_{t}$ negatief mag worden, zodat een afname van het eigen vermogen mogelijk is).

(5) $B_{t}=T_{t}-A_{t}$; met behulp van het vreemde vermogen is het totale beschikbare vermogen gelijk aan het totale geïnvesteerde vermogen.

(6) $\mathrm{W}_{\mathrm{t}}=(1-\mathrm{f})\left(\mathrm{Z}_{\mathrm{t}}-\mathrm{AFS}_{\mathrm{t}}-\mathrm{k}_{\mathrm{B}} \cdot \mathrm{B}_{\mathrm{t}-1}\right)$; zie resultatenrekening. Als parameterwaarden zijn aangenomen: $f=\frac{1}{2}$ en $k_{B}=8 \%$.

(7) $\mathrm{RS}_{\mathrm{t}}=\mathrm{W}_{\mathrm{t}}-\mathrm{DU}_{\mathrm{t}}$; zie winstverdeling.

(8) $I_{N V_{t}}=\sum_{i} \operatorname{inv}_{i, t} \cdot I_{i, t}$; het totale investeringsbedrag voor periode $t$ bestaat uit de sommatie van de investeringsbedragen der voor periode $t$ geaksepteerde projekten: voor geaksepteerde projekten geldt $\mathrm{IP}_{\mathrm{i}, \mathrm{t}}=1$, voor nietgeaksepteerde projekten geldt $\mathrm{IP}_{\mathrm{i}, \mathrm{t}}=0$. Aan het model is meegegeven een verzameling projekten, die elk een eigen investeringsbedrag kennen, alsmede een looptijd, waarin het verloop van de netto ontvangsten (cash flows) en de afschrijvingen gegeven is. In elke periode kan derhalve worden gekozen uit een aantal alternatieve projekten waarvan de relevante waarden deterministisch van aard zijn.

(9) $z_{t}=z_{0, t}+{ }_{j=1}^{t} \sum_{i}^{1} z_{i, t} \cdot I P_{i, j}$; de netto ontvangsten voor periode $t$ bestaan uit de som van de netto ontvangsten die alle tot aan $t$ geaksepteerde projekten teweegbrengen, alsmede de netto ontvangsten $z_{0, t}$ die de ,onderneming van $t=0$ " zou voortbrengen indien er geen additionele investeringen zouden zijn gedaan.

(10) $\mathrm{AFS}_{\mathrm{t}}=\mathrm{afs} \mathrm{s}_{0, \mathrm{t}}+{ }_{\mathrm{j}=1}^{\mathrm{t}} \hat{\Sigma}_{1}^{1} \sum_{\mathrm{i}} \mathrm{afs}_{\mathrm{i}, \mathrm{t}} \cdot \mathrm{IP}_{\mathrm{i}, \mathrm{j}}$; hier geldt een analoge toelichting als bij (9), maar nu voor de afschrijvingen.

Het periodiek bepalen van de waarden van de opgenomen beslissingsvariabelen impliceert enkele centrale keuzevraagstukken betreffende de financiële struktuur. Onder de veronderstelling dat de beslissingen van "strategische" aard (zoals terzake van produkten, technologie en afzetmarkten) reeds zijn genomen, wordt de hypothetische onderneming in dit model gekonfronteerd met o.m. de volgende alternatieven in de financiële planning:

a. betreffende de kapitaalgoederenstruktuur:

- keuze uit een verzameling investeringsmogelijkheden $\left(\operatorname{IP}_{i, \mathrm{t}}\right)$, verspreid over een planningstijdvak van 7 perioden;

- bepaling van de hoeveelheid kasmiddelen $\left(L_{t}\right)$ die per periode zal worden aangehouden; 
b. betreffende de vermogensstruktuur: voor het aantrekken of afstoten van vermogen kan worden gekozen uit

- eigen (ondernemend) vermogen $\left(A_{t}\right)$ : emissie van aandelen $\left(M_{t}\right)$ en/of winstinhouding $\left(R S_{t}\right)$, uitkering van winst $\left(D U_{t}\right)$ - welke zodanig kan zijn dat $\mathrm{RS}_{\mathrm{t}}$ negatief wordt;

- vreemd (niet-ondernemend) vermogen $\left(B_{t}\right)$, met een (konstante) interestlast van $8 \%$.

Aldus zijn er vele alternatieve ontwikkelingen mogelijk ten aanzien van de vanaf $\mathrm{t}=0$ gerekend - toekomstige stroom- en voorraadgrootheden. De keu$z e$, en dus de tijdruimtelijke ontwikkeling, van een aantal van deze grootheden (beheersbare variabelen in het model) wordt beperkt door onderstaande eisen en restrikties, die als aspiraties (zie par. 2.3.2) gesteld zijn aan de financiële struktuur.

Toelichting ,,aspiratievergelijkingen" (zie ook bijlage 1).

Voor de inhoud van deze aspiraties is, zoals reeds vermeld, met name aansluiting gezocht bij de onder $[2 ; 5 ; 24 ; 25]$ vermelde literatuur.

$$
R_{t}-\left(1+g_{0}^{*}\right) R_{t-1}-y_{g 0}^{*}+y_{g 0}=0
$$

maken het mogelijk een ondergrens en, indien gewenst, een bovengrens te stellen aan de groei van de reële aktiva per periode. Deze groei kan gewenst zijn uit hoofde van levensvatbaarheid op langere termijn: teneinde bepaalde produktie- en verkoopaktiviteiten te kunnen (blijven) uitvoeren is een bepaalde voorraad aktiva noodzakelijk. In het model geldt $\mathrm{g}_{0}=0,05$ en $\mathrm{g}_{\mathrm{B}}^{\mathrm{E}}=$ 0,20 ; het onder-, resp. overbereiken van deze grenswaarden kan worden tegengegaan door de afwijkingsvariabelen $\mathrm{y}_{\mathrm{g} 0}^{-}$en $\mathrm{y}_{\mathrm{gB}}^{*}$ met een positieve koëfficiënt op te nemen in de minimand.

(13) $L_{t}-k^{*} \cdot R_{t}-y_{k}^{+}+y \bar{k}=0$; op deze wijze kan de hoeveelheid liquide middelen worden ,gekoppeld" aan de reële aktiva, bijv. wegens een gewenste transaktiekas. Er is gesteld $\mathbf{k}^{*}=0,15$. Evenzo kan met behulp van

(14) $L_{t}-1^{*} \cdot B_{t}-y_{1}^{+}+y_{1}^{-}=0$ de hoeveelheid liquide middelen worden gesteld in verhouding tot de hoeveelheid aangetrokken vreemd vermogen, o.m. ter handhaving van liquiditeit en weerstandsvermogen. Als aspiratieniveau is aangenomen $1^{*}=0,30$. De voorwaarden $L_{t} \geq 0,15 R_{t}$ en $L_{t} \geq 0,30 B_{t}$ kan men trachten te bereiken door $y_{k}^{-}$en $y_{1}^{-}$met een positieve koëfficiënt op te nemen in de minimand.

$$
B_{t}-\lambda_{0}^{*} \cdot A_{t}-y_{\lambda 0}^{+}+y_{\lambda 0}^{-}=0
$$

(16) $B_{t}-\lambda_{B} \cdot A_{t}-y_{\lambda B}^{+}+y_{\lambda_{B}}^{-}=0$. Aldus is het mogelijk een onder- en bovengrens te stellen aan de verhouding tussen het vreemde en het eigen vermogen $\left(\frac{B}{A}=\lambda\right)$. Ten behoeve van een mogelijke financiële hefboomwerking is deze verhouding naar onderen begrensd $\left(\lambda_{0}^{*}=0,8\right)$, terwijl de verhouding naar boven is beperkt $\left(\lambda_{B}=1,2\right)$ in verband met o.m. weerstandsvermogen (interne kracht), kredietwaardigheid en solvabiliteit. De hoogte van de positieve koëfficiënten waarmee $y_{\lambda{ }^{-}}^{-}$resp. $y_{\lambda B}^{+}$in de minimand worden opgenomen, bepaalt de „dwingendheid" van deze onder- en bovenbegrenzing. 
(17) $R_{t}-s^{*}\left(A_{t}-A_{t-1}\right)-y_{s}^{+}+y_{s}^{-}=0$. Op deze wijze kan een zeggenschapsoverweging gestalte krijgen: van de toename van het eigen vermogen moet mininaal een fraktie $s^{*}$ (in het model $s^{*}=0,5$ ) worden verkregen door interne financiering met behulp van ingehouden winsten. In dit geval moet dan $y_{s}^{-}$worden opgenomen in de doelfunktie.

(18) $\mathrm{MS}_{\mathrm{t}}-\mathrm{MS}_{\mathrm{B}}^{+} \cdot \mathrm{d}_{\mathrm{t}}-\mathrm{y}_{\mathrm{MSB}}^{+}+\mathrm{y}_{\bar{M} \mathrm{SB}_{\mathrm{B}}}=0$

(19) $d_{t}+d_{t+1} \leq 1 ; d_{t}=0$ of $1(t=1,2, \ldots, 6)$. Op deze wijze kunnen zowel emissie-aktiviteit als emissiebedrag worden beperkt, o.m. ter vermijding van onnodige koersdruk. In het model is aangenomen $\mathrm{MS}_{\mathrm{B}}^{*}=1.000 .000$, welke waarde als bovengrens voor het emissiebedrag kan worden gehanteerd; (19) veroorzaakt dat deze bovengrens hoogstens eenmaal per 2 perioden aktueel is, nl. indien $d_{t}=1$; in het andere geval is de ,bovengrens" gelijk aan nihil, nl. als $d_{t}=0$, en mag er niet worden geëmitteerd. Dit laatste geld $t$ uiteraard slechts afhankelijk van de ,zwaarte" waarmee ýMSB $_{\mathrm{B}}$ is opgenomen in de minimand. Tevens is in de mogelijkheid voorzien een ondergrens voor het emissiebedrag te stellen; daartoe is opgenomen

(18A) $\mathrm{MS}_{\mathrm{t}}-\mathrm{MS}_{0}^{*} \cdot \mathrm{d}_{\mathrm{t}}-\mathrm{y}_{\mathrm{MSO}}^{\prime}+\mathrm{y}_{\mathrm{MSO}}=0$, waarin $\mathrm{MS}_{0}^{*}=100.000$ is gesteld; deze ondergrens wordt „effektief” indien $y_{M} S O$ in de minimand wordt opgenomen.

(20) $\mathrm{DU}_{t}-\mathrm{d}^{*} \cdot A_{t-1}-\mathrm{y}_{\mathrm{d}}^{+}+\mathrm{y}_{\mathrm{d}}=0$. Door middel van deze vergelijking kunnen aspiraties betreffende de dividenduitkering worden gesteld. Terwille van de eenvoud wordt het dividend vastgesteld als fraktie van het totale eigen vermogen aan het begin van de periode. Door y $\bar{d}$ op te nemen in de minimand wordt voor het dividend minstens naar een minimumpercentage gestreefd (in het model is $d^{*}=0,08$ ). Door ook $y^{*} d$ op te nemen, kan een streven naar dividendstabilisatie tot uitdrukking worden gebracht.

(21) $\mathrm{w}_{\mathrm{t}}-\mathrm{r}^{*} \cdot \mathrm{A}_{\mathrm{t}-1}-\mathrm{y}_{\mathrm{t}}^{+}+\mathrm{y}_{\mathrm{r}}^{-}=0$. Deze vergelijking voorziet in de mogelijkheid aspiraties op te nemen betreffende de rentabiliteit van het eigen vermogen, zulks ter behartiging van de belangen der eigenaren. In het model is $r^{*}=0,10$ gesteld, en $y_{r}^{-}$met een positieve koëfficiënt opgenomen in de minimand. Daarnaast is steeds $y_{r}^{+}$met een zeer kleine negatieve koëfficiënt opgenomen, teneinde er in te kunnen voorzien dat, indien aan alle overige gestelde aspiraties tegelijk voldaan zou zijn, voor het verhogen van de rentabiliteit van het eigen vermogen een stimulans aanwezig is. Opgemerkt zij dat het met behulp van (21) ook mogelijk is maximalisatie van de rentabiliteit na te streven, nl. door in de doelfunktie $y_{r}^{-}$streng ,af te straffen" en $y_{r}^{+}$zeer sterk te stimuleren.

Teneinde te voorkomen dat het model na periode 7 in een ,vacuum" geraakt, is van alle projekten, die op $t=7$ nog niet zijn beëindigd, een soort „restwaarde" bepaald (globaal gesteld: een in de tijd gewogen gemiddelde van netto ontvangsten minus afschrijvingen gedurende de resterende looptijd van het projekt), waaraan een minimum rentabiliteitseis wordt gesteld met behulp van een aparte aspiratievergelijking.

Doelstellingsfunktie (zie bijlage 1).

Zoals reeds vermeld in par. 3 worden de variabelen in de doelstellingsfunktie gevormd door afwijkingsvariabelen uit de aspiratievergelijkingen (,,target 
constraints"), en wel die afwijkingsvariabelen wier minimalisatie (c.q. maximalisatie) bijdraagt tot het bereiken van de gestelde aspiratie. De onderlinge verhouding tussen de koëfficiënten die worden toegevoegd aan de in de voorgaande bespreking genoemde relevante afwijkingsvariabelen, vormen een afbeelding van de prioriteiten die worden toegekend aan het bereiken van bepaalde aspiraties. In de volgende paragraaf zullen enkele uitkomsten van het model, i.c. de vertoonde ontwikkelingen van de financiële struktuur, bij alternatieve ,prioriteitenschema's" kort worden beschouwd.

\subsection{Enkele uitkomsten van het model}

Alvorens de resultaten van enkele "runs" met het model nader te beschouwen, zij nogmaals gewezen op de aard van de gevonden oplossingen. De oplossingstechniek van doelprogrammering zoekt naar die waarden der beslissingsvariabelen die het beste aansluiten bij de gestelde "doelen"; dit laatste afhankelijk van de onderlinge verhouding der koëfficiënten in de doelstellingsfunktie. Voor het onderhavige model betekent dit dat een gevonden oplossing het verloop van de financiële struktuur weergeeft dat het beste aansluit bij de gestelde aspiraties (met inachtneming van hun ,gewicht"). Het gaat om de ontwikkeling van een bevredigende financiële struktuur. Het is evenwel niet onmogelijk dat een aantal aspiraties niet geheel ,gehonoreerd" zijn wegens hun inkonsistentie met anderen, in welk geval de oplossing niet bevredigend is (zie ook par. 2.3.1).

De uitgangssituatie voor het model blijkt uit de volgende balans: ${ }^{10}$ )

Balans op $\mathrm{t}=0$

\begin{tabular}{lr|ll}
\hline $\mathrm{R}_{0}$ & 1600 & $\mathrm{~A}_{0}$ & 1000 \\
$\mathrm{~L}_{0}$ & 400 \\
$\mathrm{~T}_{0}$ & 2000 & $\mathrm{~B}_{0}$ & 1000 \\
\hline
\end{tabular}

Tevens is op voorhand vastgelegd het verloop van de netto ontvangsten $z_{0, t}$ en de afschrijvingen afs $0, t$, geldend voor de situatie dat na $t=0$ geen investeringen worden gedaan (a.h.w. de $Z$ en AFS van de "huidige" onderneming). Aangezien investeringen pas in hun eerstvolgende periode „werken", geldt steeds voor elke run: $Z_{1}=500$ en $A F S_{1}=200$. Het voert o.i. te ver op deze plaats alle afzonderlijke waarden van in $v_{t}, z_{t}$ en afs $t$ te vermelden, die behoren bij de verzameling investeringsprojekten, waaruit per periode gekozen kan worden.

We vermelden slechts de volgende algemene karakteristieken. Per periode zijn 6 tot 9 mogelijke investeringsprojekten gegeven; over de gehele planningshorizon kan in totaal uit 47 projekten worden gekozen. De looptijd van de meeste projekten bedraagt 4 à 5 perioden; derhalve liggen de afschrijvingen veelal boven de $20 \%$. De terugverdienperiode (,pay-off period") der projekten bedraagt, gemiddeld bezien, ca. 3 perioden. Het in projekten gein-

10) Alle bedragen luiden in $f 1000,-$; ook in het vervolg van deze paragraaf.

ma $a$ blz. 254 
vesteerde vermogen komt derhalve snel vrij, hetgeen „snelle" en relatief grote wijzigingen in de financiële struktuur mogelijk maakt. O.i. komt dit het illustratieve doel van het model ten goede. De rentabiliteit van ongeveer de helft der beschikbare projekten schommelt rond de $12 \%$ per periode. Van de overige variëert deze van $6 \%$ tot $20 \%$; een relatief hoge rentabiliteit gaat veelal gepaard met een relatief lange terugverdientijd (en omgekeerd). In de loop van de 7 perioden doet zich geen trend voor in de rentabiliteit of de liquiditeit der ,,aangeboden" projekten.

Onderstaand zullen de resultaten van een viertal ,runs" worden besproken. Elke „run” kenmerkt zich door een bepaald prioriteitenschema betreffende de aspiraties, hetgeen zich uit in de koëfficiënten van de afwijkingsvariabelen in de doelfunktie. In de volgende tabel 1 zijn deze koëfficiënten samengevat (vergl. ook bijl. 1):

Tabel 1

\begin{tabular}{|c|c|c|c|c|c|c|c|c|}
\hline \multirow[b]{2}{*}{$\left.\mathrm{No}^{*}\right)$} & \multicolumn{4}{|c|}{ Aspiratieniveau } & \multicolumn{4}{|c|}{$\begin{array}{l}\text { Koëfficiënt in de minimand in } \\
\text { „run" }\end{array}$} \\
\hline & Omschrijving & Symbool & Waarde & Vorm & I & II & III & IV \\
\hline 11 & Groei & $\mathrm{g}_{0}^{*}$ & $5 \%$ & ondergrens & 1 & 1 & $10^{6}$ & $10^{6}$ \\
\hline 12 & $"$ & $\mathrm{~g}_{\mathrm{B}}^{*}$ & $20 \%$ & ondergrens & & $10^{12}$ & & \\
\hline & & & & bovengrens & 1 & 1 & $10^{6}$ & $10^{6}$ \\
\hline 13 & Liquiditeit & $\mathbf{k}^{*}$ & 0,15 & ondergrens & 1 & 1 & $10^{6}$ & $10^{6}$ \\
\hline 14 & , & $1^{*}$ & 0,30 & ondergrens & 1 & 1 & $10^{12}$ & $10^{12}$ \\
\hline 15 & $\begin{array}{l}\text { Vermogens- } \\
\text { struktuur }\end{array}$ & $\lambda_{0}^{*}$ & 0,8 & ondergrens & 1 & 1 & $10^{12}$ & $10^{12}$ \\
\hline 16 & , & $\lambda_{\mathrm{B}}^{*}$ & 0,12 & bovengrens & 1 & 1 & $10^{12}$ & $10^{12}$ \\
\hline 17 & Zeggenschap & $\mathrm{s}^{\mathrm{D}}$ & 0,5 & ondergrens & 1 & 1 & $10^{6}$ & $10^{6}$ \\
\hline 18 & $\begin{array}{l}\text { Emissie- } \\
\text { aktiviteit }\end{array}$ & $\mathrm{MS}_{\mathrm{B}}^{*}$ & 1000 & bovengrens & 1 & 1 & 1 & $10^{12}$ \\
\hline $18 \mathrm{~A}$ & ", & $\mathrm{MS}_{0}^{*}$ & 100 & ondergrens & & & & $10^{12}$ \\
\hline 20 & Dividend & $d^{*}$ & $8 \%$ & $\begin{array}{l}\text { ondergrens } \\
\text { bovengrens }\end{array}$ & 1 & 1 & $10^{6}$ & $\begin{array}{l}10^{6} \\
10^{6}\end{array}$ \\
\hline 21 & Rentabiliteit & $\mathrm{r}^{*}$ & $10 \%$ & $\begin{array}{l}\text { ondergrens } \\
\text { overschrijding }\end{array}$ & $\begin{array}{c}1 \\
-10^{-3}\end{array}$ & $\begin{array}{c}1 \\
-10^{-3}\end{array}$ & $\begin{array}{c}10^{6} \\
-10^{-3}\end{array}$ & $\begin{array}{c}10^{6} \\
-10^{-3}\end{array}$ \\
\hline
\end{tabular}

*) Vergl. de nummering in bijlage 1.

\section{Run I}

Alle relevante afwijkingsvariabelen zijn gelijk ,gewogen", m.u.v. de $y_{r}^{+}$(overbereiking van de rentabiliteitsaspiratie), die een zeer lichte stimulans heeft. Het resultaat van de computer-,,run" met dit prioriteitsschema is weergegeven in de tabel van bijlage 2 . Slechts op 3 punten blijkt niet aan de aspiratie- 
niveaus te zijn voldaan: in periode 1 overtreft de groei de gestelde bovengrens (deze sterke groei was kennelijk noodzakelijk om voor de volgende perioden een voldoende Z-stroom te bewerken, teneinde aan de overige aspiraties te voldoen!); in periode 1 en 4 wordt de zeggenschapsrestriktie geschonden (deze restriktie stelt hoge eisen aan de winst, en is bepaald strijdig te noemen met de dividend-aspiraties). Opgemerkt zij dat deze 3 ,,schendingen" der aspiraties ook blijken uit de waarden der afwijkingsvariabelen, die ter toelichting onder in de tabel zijn opgenomen.

Een grafische voorstelling van de belangrijkste variabelen uit de tabel van bijlage 2 wordt gegeven in de figuren IA en IB van bijlage 3. In de figuur IA is afgebeeld het tijdruimtelijk verloop van de kombinaties van eigen en vreemd vermogen (het eerste is afgezet langs de horizontale as, het laatste langs de vertikale as; $\lambda_{0}^{*}$ en $\lambda_{\mathrm{B}}^{*}$ geven de onder-en bovengrens weer, die is gesteld aan de verhouding tussen het vreemde en het eigen vermogen; de cijfers $1 \mathrm{t} / \mathrm{m} 7$ duiden op de ,vermogensposities" op $\left.t=1, \ldots, 7) .^{11}\right)$ In de figuur IB is afgebeeld het verloop van de hoeveelheid liquide middelen (L), de reële aktiva $(R)$ en het totale geïnvesteerde vermogen $(T)$, als funktie van de tijd $(\mathrm{t})$.

\section{Run II}

Blijkens tabel 1 is de enige verandering t.o.v. de voorgaande run, dat hier de hoogste prioriteit is gegeven aan het bereiken van een groei van $\mathrm{R}$ van $20 \%$ per periode. Het resultaat is afgebeeld in de figuren IIA en IIB van bijlage 3. Vergelijking met de figuren IA en IB wijst uit dat inderdaad de groei aanzienlijk sterker is (overigens na aanvankelijk zeer aarzelend te zijn begonnen; hieraan is mede schuldig de karakteristiek der investeringsprojekten). De vermogensstruktuur, verhouding tussen $B$ en $A$, koncentreert zich minder bij de bovengrens $\lambda_{B}^{*}$ dan in het vorige geval: de zeer sterke groei,dwang" overschaduwt de geringe rentabiliteitsprikkel, zodat minder gebruik wordt gemaakt van de financiële hefboomwerking. Als geschonden aspiratieniveaus zijn te melden:

- de geaspireerde groei van $20 \%$ wordt slechts in de laatste periode behaald; in de eerste periode blijft de groei zelfs beneden de $5 \%$;

- de liquiditeitsaspiratie (14) wordt in de periode 6 niet gehaald;

- de zeggenschapsrestriktie (17) wordt bij emissie steeds geschonden (de emissies vinden plaats in de perioden 2,4 en 7 );

- in periode 1 en 6 wordt de dividend-aspiratie (20) geschonden (in de 6e periode wordt nagenoeg geen dividend uitgekeerd, alle middelen worden gebruikt voor interne financiering).

Opgemerkt zij dat de rentabiliteitsaspiratie (21) steeds wordt gehonoreerd, hoewel in de perioden 3 en 4 er geen overschrijding plaats vindt: er is juist aan de $10 \%$-eis voldaan.

11) Het idee voor deze figuur is a fkomstig uit [5, p. 411].

$m a b$ blz. 256 


\section{Run III}

In deze run zijn de aspiraties op een andere wijze ingedeeld in een aantal prioriteitsklassen; de hoogste prioriteit is toegekend aan de aspiraties ten aanzien van de verhouding tussen het vreemde en het eigen vermogen $(0,8 \leq$ $\left.\lambda^{*} \leq 1,2\right)$ en aan de liquiditeitsrestriktie $1^{*} \geq 0,30$. Het verloop van de financiële struktuur is afgebeeld in de figuren IIIA en IIIB in bijlage 3. De groei van $\mathrm{R}$ beweegt zich steeds (m.u.v. periode 1: $\mathrm{g}>20 \%$ ) tussen de onderen bovengrens. De vermogensstruktuur profiteert, met inachtneming van de $\lambda$-grenzen, in de meeste gevallen zoveel mogelijk van de financiële hefboomwerking. Slechts de volgende aspiraties worden geschonden:

- groei in periode 1 is meer dan $20 \%$;

- er wordt geëmitteerd in de perioden $1,2,3,4,5$ en 7 : in 2 en 4 wordt derhalve de restriktie (18) geschonden (daar voor $t=2$ en $t=4$ geldt dat $d_{t}$ $=0$ );

- de zeggenschapsrestriktie (17) wordt geschonden in de perioden 1 en 3 (in de overige perioden waren de emissiebedragen zo klein dat de ingehouden winsten voldoende waren om aan (17) te voldoen).

\section{Run IV}

Teneinde het te veelvuldig emitteren tegen te gaan is de afwijkingsvariabele $y_{M S B}^{\prime}$ (zie aspiratievergelijking (18)) naar de hoogste prioriteitenklasse geplaatst, en tevens is (18A) effektief gemaakt door $\gamma_{\bar{M}}{ }_{B B}$ in dezelfde klasse op te nemen (waardoor een geaspireerde ondergrens voor het emissiebedrag wordt gesteld). Bovendien is in deze run een streven naar dividendstabilisatie ingevoerd door $\vec{y}_{d}^{+}$in de minimand op te nemen. De resultaten zijn afgebeeld in de figuren IVA en IVB van bijlage 3. Opmerkelijk is dat de vermogensstruktuur zich minder ,langs de $\lambda_{\mathrm{B}}$-lijn" beweegt, dan bij de voorgaande run: de dwang minder frekwent grotere bedragen eigen vermogen aan te trekken is hiervan de oorzaak (emissies vinden plaats op $t=1,3,5$ en 7 ). Het streven naar dividendstabilisatie veroorzaakt in periode 5 een duidelijke overliquiditeit $(1=0,38)$.

Als geschonden aspiraties kunnen genoemd worden:

- de groei bedraagt in periode 1 meer dan $20 \%$, en in periode 7 minder dan $5 \%$;

- de zeggenschapsaspiratie (17) wordt geschonden in periode 1 en 3 (en zeer licht in periode 7);

- in periode 3 wordt de dividendaspiratie (20) net niet gehaald.

\section{Slotopmerkingen}

De in het voorgaande getoonde ontwikkelingen van een bevredigende financiële struktuur beogen een illustratie te geven van de wijze waarop via doelprogrammering rekening gehouden kan worden met gestelde aspiraties. Het sterk geabstraheerde karakter van dit model blijkt o.m. uit het feit dat geen rekening is gehouden met het proces van tijdruimtelijke aanpassing van de aspiratieniveaus aan de bereikte resultaten. In een realistische afbeelding 
van het ondernemingsgedrag mag dit proces zeker niet ontbreken. Dat aan de uitkomsten van het model vooralsnog niet meer dan illustratieve waarde gehecht kan worden, is mede gelegen in de twee volgende redenen:

1 De verzameling investeringsprojekten, waaruit het model kan putten, bepaalt in belangrijke mate de ontwikkeling der variabelen; de investeringsprojekten zijn evenwel betrekkelijk willekeurig. Andere projekten zouden naar alle waarschijnlijkheid resulteren in een ander ,gedrag" van het model.

2 Het rekenprogramma ${ }^{12}$ ), waarmee de uitkomsten van het model zijn bepaald, hanteert in zijn tweede fase (het zoeken naar toelaatbare oplossingen binnen de voorwaarde van de geheeltalligheid der als zodanig gedefinieerde variabelen $t$.w. $I P_{i, t}, d_{t}$ ) een zgn. ,, branch and bound" procedure. Dit impliceert dat via een systematisch zoekproces alle mogelijke oplossingen op hun toelaatbaarheid worden geselekteerd. In het kader van de satisfactie-gedachte hebben wij de rekentijd begrensd tot een maximum - voor alle „runs" overigens gelijk. Dit houdt evenwel in dat bij meer rekentijd de gevonden oplossingen naar alle waarschijnlijkheid nog verbeterd kunnen worden, in die zin dat nog minder aspiraties, c.q. de aspiraties nog minder, geschonden zouden worden. Aangezien de te verwachten "verbeteringen" in de meeste gevallen niet meer dan marginaal zullen zijn, menen wij dat bij ca. 1800 iteraties ons aspiratieniveau betreffende de rekentijd wel is bereikt.

\section{LITERATUURLIJST}

1 H. I. Ansoff, Corporate Strategy. New York, 1965.

2 J. L. Bouma, Ondernemingsdoel en Winst: een confrontatie van enkele theorieën van het ondernemingsgedrag. Leiden, 1966.

$3-$, De Toepassing van Intern-gedragsmodellen in de Bedrijfseconomie. Leiden, 1967.

4 -, Leerboek der Bedrijfseconomie, deel IA. Den Haag, 1968.

5 -, Leerboek der Bedrijfseconomie, deel II. Wassenaar, 1971.

6 -, Gedragswetenschappelijke Aspecten van de Bedrijfseconomische Problematiek, Maandblad voor Bedrijfsadministratie en -Organisatie, 76 (1972) nr. 898.

12) Wij betuigen onze dank aan Ir. C. L. J. van der Meer, medewerker aan het Instituut voor Economisch Onderzoek van de Economische Faculteit te Groningen, voor zijn hulp bij de rekentechnische verwerking van het model.

De berekeningen werden uitgevoerd op het Rekencentrum van de Rijksuniversiteit te Groningen met een computerprogramma voor geheeltallig programmeren, ontwikkeld door het Mathematisch Centrum te Amsterdam.

$m a b$ blz. 258 
7 A. Bosman, Het handelen in de Economie, I en II, Maandblad voor Bedrijfsadministratie en -Organisatie, 76 (1972) nrs. 905 en 908.

8 R. M. Cyert en J. G. March, A Behavioral Theory of the Firm. Englewood Cliffs, 1963.

9 A. Charnes and W. W. Cooper, Management Models and Industrial Applications of Linear Programming, vol I and II. New York, 1961.

$10-,-$ and R. Ferguson, Optimal Estimation of Executive Compensation by Linear Programming, Management Science, Vol. 1, no. 2 (January 1955).

$11-,-$ and Y. IJiri, Break-even Budgetting and Programming to Goals, Journal of Accounting Research, 1, Spring 1963.

12 J. F. Courtney, T. D. Klastorin and T. W. Ruefli, A Goal Programming Approach to Urban-Suburban Location Preferences, Management Science, vol. 18, no. 6 (February 1972).

13 A. I. Diepenhorst, Structuur en Politiek. Purmerend, 1961.

14 F. Hartog, Theorie van de Onderneming; Algemeen-economische tegenover Bedrijfseconomische Optiek, Economisch-Statistische Berichten, 22 sept. 1971.

15 Y. IJiri, Management Goals and Accounting for Control. Amsterdam, 1965.

16 -, F. K. Levy and R. C. Lyon, A Linear Programming Model for Budgetting and Financial Planning, Journal of Accounting Research, 1, Autumn 1963.

17 S. E. de Jong, Financieringsfunctie en Financieringsterrein; recente ontwikkelingen in de theorie van de ondernemingsfinanciering, Maandschrift Economie, juni 1972.

18 S. M. Lee and E. R. Clayton, A Goal Programming Model for Academic Resource Allocation, Management Science, vol. 18, no. 8 (april 1972).

19 J. G. March and H. A. Simon, Organizations. New York, 1958.

20 J. C. T. Mao, Quantitative Analysis of Financial Decisions. London, 1969.

21 A. Nentjes, Marginalisme en Behaviorisme in de Theorie van de Onderneming, Economisch-Statistische Berichten, 24 nov. 1971.

22 G. G. J. M. Poeth en S. I. Stemne, Een Beschouwing over de Doelstellingsfunctie van de Onderneming, Maandblad Bedrijfskunde, mei 1972.

23 H. A. Simon, A Behavioral Model of Rational Choice, Models of Man; Social and Rational. New York, 1957.

24 L. Traas, Het Investerings- en Financieringsplan van de Onderneming. Alphen a.d. Rijn, 1968.

25 H. Willems, De Financiële Structuur en de Vermogenskosten in de Investeringsplanning en de Kostprijsberekening. Leiden, 1965. 
Bijlage 1

MODELBESCHRIJVING, voor periode $\mathrm{t}(\mathrm{t}=1,2, \ldots, 7)$

"Boekhoudkundige relaties":

(1) $\mathrm{R}_{\mathrm{t}}-\mathrm{R}_{\mathrm{t}-1}+\mathrm{AFS}_{\mathrm{t}}-\mathrm{INV}_{\mathrm{t}}=0$

(2) $\mathrm{L}_{\mathrm{t}}-\mathrm{L}_{\mathrm{t}-1}-\mathrm{W}_{\mathrm{t}}-\mathrm{AFS}_{\mathrm{t}}+\mathrm{DU}_{\mathrm{t}}-\mathrm{MS}_{\mathrm{t}}-\mathrm{B}_{\mathrm{t}}+\mathrm{B}_{\mathrm{t}-1}+\mathrm{INV}_{\mathrm{t}}=0$

(3) $\mathrm{T}_{\mathrm{t}}-\mathrm{R}_{\mathrm{t}}-\mathrm{L}_{\mathrm{t}}=0$

(4) $A_{t}-A_{t-1}-R S_{t}-M S_{t}=0$

(5) $B_{t}-T_{t}+A_{t}=0$

(6) $\mathrm{W}_{\mathrm{t}}-0,5 \mathrm{Z}_{\mathrm{t}}+0,5 \mathrm{AFS}_{\mathrm{t}}+0,04 \mathrm{~B}_{\mathrm{t}-1}=0$

(7) $\mathrm{RS}_{\mathrm{t}}-\mathrm{W}_{\mathrm{t}}+\mathrm{DU}_{\mathrm{t}}=0$

(8) $\operatorname{INV}_{\mathrm{t}}-\sum_{\mathrm{i}}$ inv $_{\mathrm{i}, \mathrm{t}} \cdot \mathrm{IP}_{\mathrm{i}, \mathrm{t}}=0 \quad\left(\mathrm{IP}_{\mathrm{i}, \mathrm{t}}=0\right.$ of 1$)$

(9) $\mathrm{z}_{\mathrm{t}}-\mathrm{z}_{0, \mathrm{t}}-{ }_{\mathrm{j}}^{\mathrm{t}} \bar{\Sigma}_{1}^{1} \sum_{\mathrm{i}} \mathrm{z}_{\mathrm{i}, \mathrm{t}} \cdot \mathrm{IP}_{\mathrm{i}, \mathrm{j}}=0$

(10) $\mathrm{AFS}_{\mathrm{t}}-\mathrm{afs}_{0, \mathrm{t}}-{ }_{\mathrm{j}}^{\mathrm{t}} \sum_{1}^{1} \sum_{\mathrm{i}} \mathrm{afs}_{\mathrm{i}, \mathrm{t}}-\mathrm{IP}_{\mathrm{i}, \mathrm{j}}=0$

"Aspiratievergelijkingen"1,

(11) Groei:

(12) Groei:

(13) Liquiditeit:

(14) Liquiditeit:

(15) Vermogens-

struktuur

(16) Vermogens-

struktuur:

(17) Zeggenschap:

(18) Emissie-aktiviteit:

(18A) Emissie-aktiviteit:

(20) Dividend:

(21) Rentabiliteit:
$\mathrm{R}_{\mathrm{t}}-\left(1+\mathrm{g}_{0}^{*}\right) \mathrm{R}_{\mathrm{t}-1}-\mathrm{y}_{\mathrm{g} 0}^{+}+\mathrm{y}_{\mathrm{g} 0}^{-}=0$

$R_{t}-\left(1+g_{B}^{*}\right) R_{t-1}-y_{g B}^{+}+y_{g B}^{-}=0$

$L_{t}-k^{*} \cdot R_{t}-y_{k}^{+}+y_{k}^{-}=0$

$\mathrm{L}_{\mathrm{t}}-\mathrm{l}^{*} \cdot \mathrm{B}_{\mathrm{t}}-\mathrm{y}_{1}^{+}+\mathrm{y}_{\mathrm{l}}^{-}=0$

$B_{t}-\lambda_{0}^{\cdot} \cdot A_{t}-y_{\lambda 0}^{+}+y_{\lambda 0}^{-}=0$

$\mathrm{B}_{\mathrm{t}}-\lambda_{\mathrm{B}}^{*} \cdot \mathrm{A}_{\mathrm{t}}-\mathrm{y}_{\lambda \mathrm{B}}^{+}+\mathrm{y}_{\lambda \mathrm{B}}^{-}=0$

$R S_{t}-s^{*}\left(A_{t}-A_{t-1}\right)-y_{s}^{+}+y_{s}^{-}=0$

$\lambda_{\mathrm{B}}^{*}=1,2$

$\mathrm{s}^{*}=0,5$

$\mathrm{MS}_{\mathrm{B}}^{*}=1000$

$\mathrm{MS}_{\mathrm{i}}^{*}=100$

$\mathrm{g}_{0}^{*}=0,05$

$\mathrm{g}_{\mathrm{B}}^{*}=0,20$

$\mathrm{k}^{*}=0,15$

$1^{*}=0,30$

$\lambda_{0}^{*}=0,8$

$M S_{t}-M S_{B}^{*} \cdot d_{t}-y_{M S B}^{*}+y_{M S B}^{-}=0$

$M S_{t}-M S_{0}^{*} \cdot d_{t}-y_{M S O}^{+}+y_{M S O}^{-}=0$ waarbij geldt: (19) $d_{t}+d_{t+1} \leq 1$

$$
d_{t}=0 \text { of } 1(t=1,2, \ldots, 6)
$$

$D U_{t}-d^{*} \cdot A_{t-1}-y_{d}^{+}+y_{d}^{-}=0$

$W_{t}-r^{*} \cdot A_{t-1}-y_{r}^{+}+y_{t}^{-}=0$

$d^{*}=0,08$

$\mathrm{r}^{*}=0,10$

Doelstellingsfunktie:

Minimaliseer $\underset{\mathrm{t}}{\sum_{=}^{7}}\left[\left(\mathrm{~W}_{1, \mathrm{t}} \cdot \mathrm{y}_{\mathrm{g} 0}^{+}+\mathrm{W}_{2, \mathrm{t}} \cdot \mathrm{y}_{\mathrm{g} 0}^{-}\right)+\left(\mathrm{W}_{3, \mathrm{t}} \cdot \mathrm{y}_{\mathrm{gB}}^{+}+\mathrm{W}_{4, \mathrm{t}} \cdot \mathrm{y}_{\mathrm{gB}}^{-}\right)+\ldots\right.$ $\left.\ldots+\left(W_{21, t} \cdot y_{r}^{+}+W_{22, t} \cdot y_{r}^{-}\right)\right]$

ma $a$ blz. 260 
Bijlage 2

Resultaten van ,run” I.

\begin{tabular}{ll|r|r|r|r|r|r|r}
\hline \multirow{2}{*}{$\begin{array}{l}\text { VARIABELE: } \\
\text { (bedragen x f 1000,-) }\end{array}$} & \multicolumn{7}{|c}{ PERIODE } \\
\cline { 3 - 8 } & & \multicolumn{1}{|c|}{1} & 2 & 3 & 4 & 5 & 6 & 7 \\
\hline Reële kapitaal & $\mathrm{R}$ & 2000 & 2380 & 2590 & 2870 & 3100 & 3440 & 3690 \\
Liquide middelen & $\mathrm{L}$ & 392 & 433 & 507 & 562 & 607 & 649 & 722 \\
Tot. geinv. vermogen & $\mathrm{T}$ & 2392 & 2813 & 3097 & 3432 & 3707 & 4089 & 4412 \\
Eigen vermogen & $\mathrm{A}$ & 1329 & 1370 & 1408 & 1560 & 1685 & 1926 & 2005 \\
Vreemd vermogen & $\mathrm{B}$ & 1063 & 1443 & 1689 & 1872 & 2022 & 2136 & 2407 \\
& & & & & & & & \\
Netto ontvangsten & $\mathrm{Z}$ & 500 & 750 & 1050 & 1270 & 1680 & 1920 & 1940 \\
Afschrijvingen & $\mathrm{AFS}$ & 200 & 370 & 640 & 770 & 1020 & 1210 & 1300 \\
Netto winst & $\mathrm{W}$ & 110 & 147 & 147 & 182 & 255 & 274 & 233 \\
$\begin{array}{l}\text { Dividend } \\
\text { Ingeh. winst }\end{array}$ & $\mathrm{DU}$ & 80 & 106 & 110 & 113 & 130 & 135 & 154 \\
Emissie v. aandelen & $\mathrm{RS}$ & 30 & 41 & 38 & 70 & 125 & 139 & 79 \\
\hline
\end{tabular}

\begin{tabular}{|c|c|c|c|c|c|c|c|c|}
\hline ASPIRATIE: ${ }^{2}$ ) & -NIVEAU: & & & & & & & \\
\hline Groei $(11,12)$ in $\%$ & $5 \leq g<20$ & 25,0 & 19,0 & 8,8 & 10,8 & 8,0 & 11,0 & 7,3 \\
\hline Liquiditeit $(13)^{3}$ ) & $1 \geq 0,30$ & 0,37 & 0,30 & 0,30 & 0,30 & 0,30 & 0,30 & 0,30 \\
\hline Verm. struktuur & $\lambda \geq 0,8$ & & & & & & & \\
\hline$(15,16)$ & $\lambda \leq 1,2$ & 0,80 & 1,05 & 1,20 & 1,20 & 1,20 & 1,12 & 1,20 \\
\hline Zeggenschap (17) & $s \geq 0,5$ & 0,09 & 1 & 1 & 0,46 & 1 & 0,58 & 1 \\
\hline $\begin{array}{l}\text { Emissie-aktiviteit } \\
\text { (19) }\end{array}$ & $\begin{array}{l}\max .1 \times \mathrm{p} . \\
2 \text { perioden }\end{array}$ & $*$ & - & - & $*$ & - & $*$ & - \\
\hline $\begin{array}{l}\text { Dividend }(20) \text { in \% } \\
\text { Rentabiliteit }\end{array}$ & $\mathrm{d} \geq 8$ & 8,0 & 8,0 & 8,0 & 8,0 & 8,35 & 8,0 & 8,0 \\
\hline (21) in $\%$ & $\mathrm{r} \geq 10$ & 11,0 & 11,0 & 10,7 & 12,9 & 16,3 & 16,25 & 12,1 \\
\hline
\end{tabular}

\begin{tabular}{c|l|l|l|l|l|l|l|l}
\hline ENKELE & & & & & & & & \\
AFWIJKINGS- & & & & & & & & \\
VARIABELEN: & & 80 & 0 & 0 & 0 & 0 & 0 & 0 \\
$(12)$ & $\mathrm{y}_{\mathrm{gB}}^{*}$ & 134 & 0 & 0 & 6 & 0 & 0 & 0 \\
\hline
\end{tabular}

1) Aangezien ook de afwijkingsvariabelen steeds voor elke periode gelden, zouden alle y"en en $y^{-}$-en ook nog voorzien moeten zijn van een index $t$; deze is echter achterwege gelaten terwille van de overzichtelijkheid.

2) Vergl. de nrs. der aspiratievergelijkingen in bijlage 1.

3) Aangezien de tweede liquiditeits-aspiratie (14) in alle gevallen minder „knellend" was dan deze (13), zijn de waarden voor $k(=\mathrm{L} / \mathrm{R})$ niet opgenomen. Ook de aspiratie m.b.t. het emissiebedrag is in deze tabel niet vermeld. 
Bijlage 3

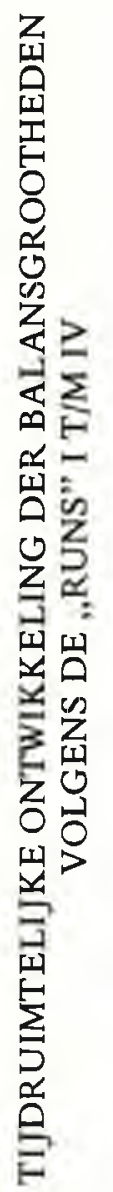

mab blz. 262
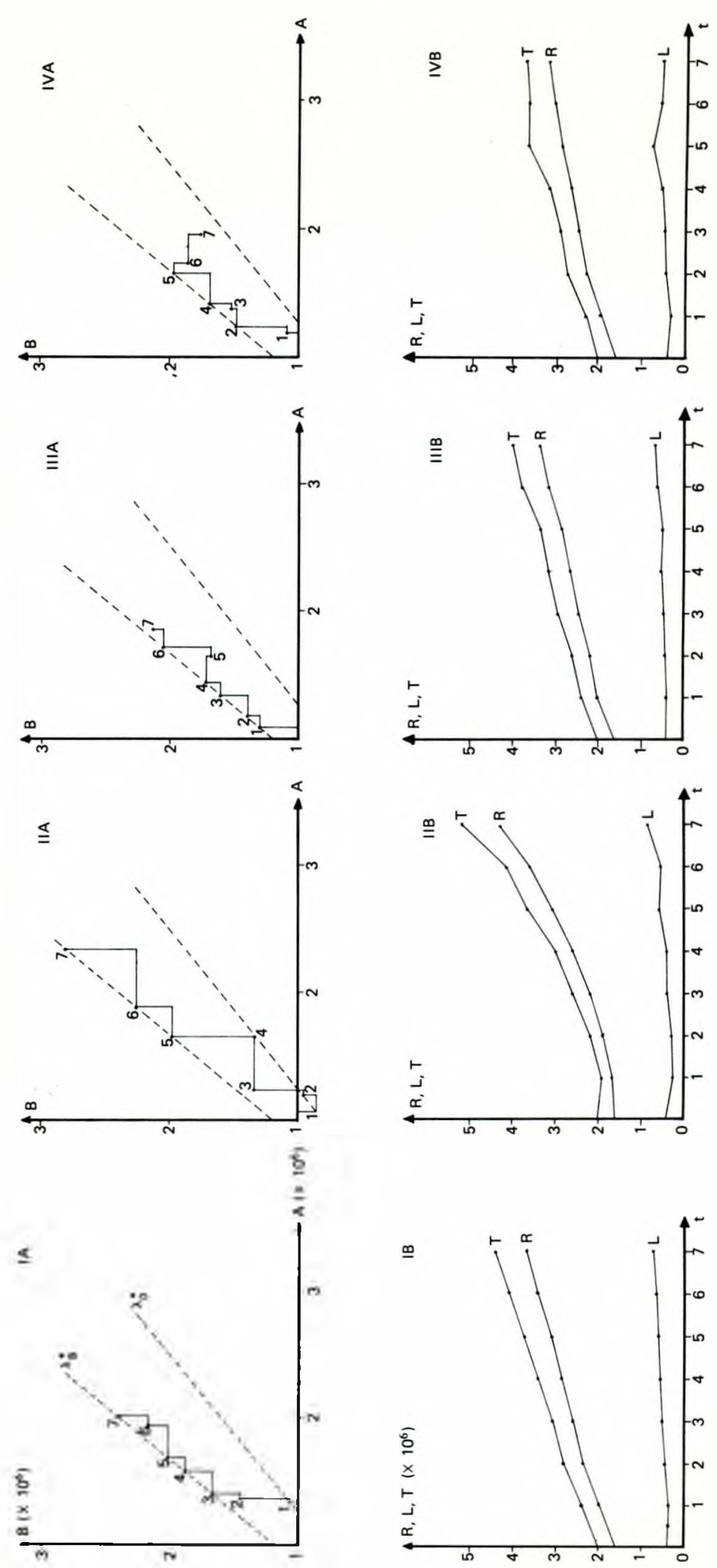